\title{
Analyzing the Efficiency of Argumentation Based Practices on 9th Grade Functions Subject ${ }^{\mathrm{i}}$
}

\author{
Emel Mercan*, Tevfik İşleyen \\ Kazım Karabekir Faculty of Education, Atatürk University, Turkey
}

Copyright $(2017$ by authors, all rights reserved. Authors agree that this article remains permanently open access under the terms of the Creative Commons Attribution License 4.0 International License

\begin{abstract}
The purpose of this study is to investigate the effect of teaching 9th grade Functions subject through argumentation on students' science process skills, attitudes towards Maths, willingness for argumentation and conceptual comprehension. The study was designed as a quasi-experimental model with pretest-posttest control group. It was carried out with 60 students totally at two different 9th classes of a Science High School in a city located in the Eastern Anatolian Region during fall semester of 2014-2015 educational years. One of these two classes was selected as the experiment group (20 female-10 male) and the other one was selected as the control group (17 female-13 male) randomly before the practice. The study was implemented in "Functions" unit. Considering the results, it was concluded that argumentation method had a positive effect on science process skills of the experiment and control group students and AWS implemented only to control group increased the argumentation willingness of the students and the conceptual comprehension frequency of experiment group students were more than the control group students.
\end{abstract}

Keywords Argumentation, Conceptual Understanding, Scientific Process Skills, Attitude to Mathematics

\section{Introduction}

The concept of function, one of the headstones of Mathematics, has a large and important place in curriculum and it is related to many subjects. A person encounters with the concept of function in each stage of his or her education from early ages to university and uses this concept in problem-solving. For instance, corresponding concrete objects with numbers in teaching process of number concept (corresponding one apple with the number 1 and corresponding a set of 2 glasses with the number 2 , etc.) or one-to-one correspondence of people with their birth dates explain the idea of function [1].

\subsection{Functions in Maths Learning}

The concept of function is also explained as the relationship between two or more variables in Maths, daily life, and Science. Students not only encounter with the concept of function in their daily life but also solve many problems and do practices with this concept. In other words, students under the school age in their daily lives improve that each person may have his or her own birth day, each country may have a capital city and each person may have only one blood type. In fact, this improving knowledge explains that the idea of function concept was established in the logic of correspondence. It can be said that the students learning the four operations in counting numbers in Maths use the concept of function without noticing [2]. Because in $2+1=3$ operation addition $(+)$ operator takes two items in reel numbers as the input and it changes a new item such as 3 occurring after the operation to the output. Therefore, function, in general, can be explained as a process changing the inputs to the outputs [1].

Throughout its historical development, the concept of function has been defined by using different parameters by many mathematicians. From these definitions, Dirichlet/Bourbaki's definition (Mid-20th century) within the base of set correspondence as "A relation between two non-empty sets such as A and B corresponding each item of A to only one item of $B$ " has affected the conception and teaching of function today most. Secondary Education Mathematics Curriculum has adopted the set correspondence definition of a function in our country as in many countries.

Students in our country encounter with the concept of function in the first year of high school education firstly and throughout their next learning lives, they have the opportunity to learn this concept. Students in 9th-grade encounter with two different features of function. First one is that each item in domain corresponds to one item from codomain; the second one is that an item in domain corresponds to maximum one item from codomain. Also, these two conceptions state that a relation should verify two basic features in order to be a function.

The concept of function throughout the Maths curriculum is related to almost all subjects of Maths. The fact that students learn the functions subject will facilitate their learning about many related subjects; however, the fact that they cannot comprehend this subject will cause an important 
problem in the comprehension of other subjects. Thus, in many researches with university and high school students it was emphasized that although the subject of functions is one of the subjects of many subjects in Maths curriculum, it is one of the subjects that students have difficulty in learning most [3-7]. In this context, teaching functions at a better level and using different methods in teaching process take on a different significance.

The fact that the concept of function is one of the concepts which students have difficulties in learning and misconceptions [8] referred those alternative methods should be used in the teaching of this concept and brought up the question of how can we teach better. In order to teach better, we should utilize some active learning strategies based upon group studies such as student-centered teaching, problem and event-based learning and pear discussion. One of the class environments where students create their own knowledge by themselves by thinking, commenting and participate in the lesson with the group work is argumentation model [9].

\subsection{Argumentation Model}

Argumentation model can be defined as the process that individuals convince the other individuals on the opposite side with the arguments who have about a concept or a theory, confute the arguments the opposite sides have or agree on them $[10,11]$. What is important in argumentation process is that although individuals have opposite ideas, students become aware of how these are important in reaching the solution while obtaining alternative thinking's and solutions with the argumentation [11]. Toulmin in his book called The Uses of Argument analyzing the natural process of argumentation which presented a model defining the basic elements of arguments and indicating the functional relationship between them. The purpose of Toulmin's argumentation model is to present the components of reasoning in exhilarating from data or dealing with information claims. Toulmin's argumentation model (1958) consists of 6 elements in general. Claim, data and reason elements from these six elements form the base of an argument. However, supporting, confusing and restrictive elements state the assistant and secondary elements. Toulmin stated the argumentation model as [12]:

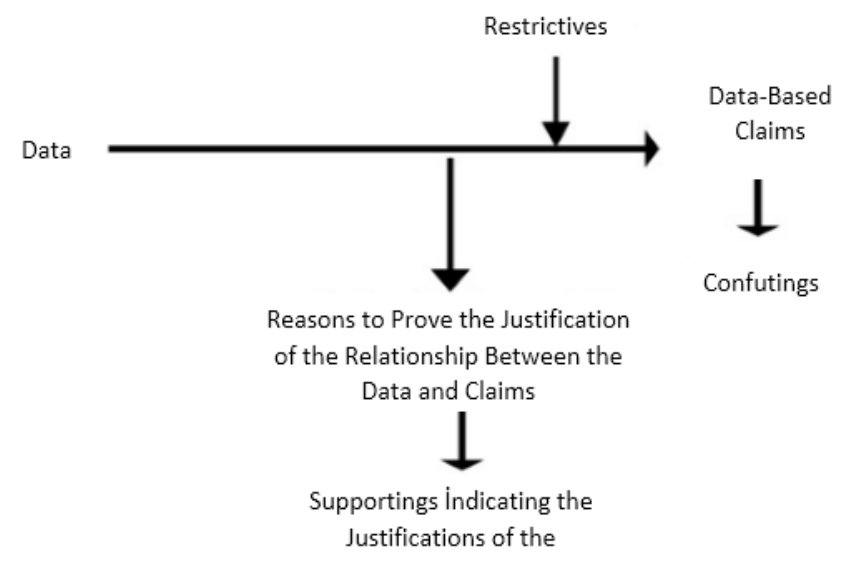

Figure 1. Toulmin's Argumentation Model [12]
This model presented by Toulmin foresees that the indicated six elements will progress related to each other in the structure of a mounted argument. The model consists of a claim and data supporting this claim, reasons indicating the relationship between the data and the claim, a supportive increasing the intenseness of the reasons, a restrictive indicating the cases that the argument is valid and finally confuses indicating the cases that the claim is not valid [13].

Main purpose of maths education through argumentation is that students can mount their own arguments about a certain topic, concept, etc., uphold and justify these mounted arguments, support them with their own knowledge, confuse them, recognize the similarities and differences between other arguments and their own arguments and achieve mathematical thinking as a result [14].

When the studies on argumentation are analyzed, these studies focus on science teaching and research on teaching maths have begun to be carried out [15-21]. In some studies, related to science education [22-30], it was observed that the students who were taught by the argumentation model have higher academic achievement, scientific process skills and conceptual understanding than those who were not taught by the argumentation model. Moreover, in some studies conducted in science education [22-24,26,27,30-33], the students who were taught with the argumentation model increased their willingness to discuss and developed their argumentation skills. It was also observed that the use of the argumentation model in science education has led students to develop a positive attitude towards science courses $[22,26$, 28, 29].

A limited number of studies were related to the use of argumentation in mathematics education. Among those who investigated argumentation model, Küçük Demir [20] investigated the effect of argumentation on maths success and creative thinking skill of 9th-grade students and reported that argumentation affected the success of functions and creative thinking skill positively as a result of the research. Dinçer [21] in his study analyzed the structure of the steps of the students in arguments created in maths undergraduate courses, especially their reasoning and their interaction with their teachers and each other. Brown and Reeves [15] in their studies analyzed mathematical skills and comprehension of the students in a learning process with argumentation method, their levels of using mathematical operations in problem-solving, expressing problems mathematically and their problem-solving skills. According to the obtained findings, it was identified that these skills improved; however, we had little information about the effect of student participation in the courses on mathematical learning out of the class. Mueller [17] in his research analyzed the effect of group work on student success and group discussions in his study with secondary school students studying in a city center. As a result of the analysis, he stated that group works had contributions to build a consensus in discussions of students in group and development of their arguments. 


\subsection{Purpose of the Study}

The function concept, which is an important issue in the mathematics curriculum, is a mathematical thought that students have difficulty in understanding and develop the misconceptions about this topic [5]. The basic factors that make the functions difficult are the presence of many concepts such as constant function, inverse function, one-to-one function and fractional function, as well as, the frequent use of different representations for the representations of the functions including graphical representation, algebraic expressions, venn diagram, list and tabular representations [2]. The concept of function is one of the concepts that students experienced difficulty to learn and fell into misconceptions [8] pointed out that alternative method should be used in the teaching of this concept and it has brought the question of how we can provide better teaching. Deficient parts of the current teaching methods were reported in many researchers' studies [34-36] related to the lessons carried out with them, to the perceptions of the students at the high school level on the concept of function and to verbal, algebraic and graphical representations of the functions. In order to achieve this, it is necessary to use different methods in teaching mathematics to prepare environments where students can say their own ideas, defend them, have conviction about correctness and fault, and try to increase their attitudes and achievements towards mathematics.

When the studies in Maths through argumentation method are analyzed, it can be observed that how the students' academic success, creative thinking skills, reasoning in discussion situations, problem-solving skills, mathematical skill levels, interaction with each other and teachers were handled. However, we cannot see any study analyzing the students' science process skills, attitude towards Maths, willingness for argumentation and conceptual comprehension with argumentation method. For that reason, this study is required to analyze the effect of argumentation method on students' science process skills, attitude towards Maths, willingness for argumentation and conceptual comprehension.

The purpose of this study is to compare the effect of argumentation method with the traditional teaching method in teaching functions subject on students' science process skills, attitude towards maths, willingness for argumentation and conceptual understanding. For that purpose, the following questions were tried to be answered in order to analyze the argumentation process occurred in maths courses with argumentation method:

1. What is the difference between the science process skills of experimental group students who received argumentation method with that of those in control group who received traditional method in learning 9th-grade functions subject?

2. What is the difference between experimental and control group students' attitudes towards maths after the interventions on learning $9^{\text {th }}$ grade function subject?
3. What is the difference between experimental and control group students' conceptual understanding after the interventions on learning $9^{\text {th }}$ grade function subject?

4. What is the difference between experimental and control group students' willingless for argumentation after the interventions on learning $9^{\text {th }}$ grade function subject?

\section{Method}

\subsection{Model of the Study}

This study aims to identify the effect of teaching through argumentation method on students' science process skills, attitude towards Maths, willingness for argumentation and conceptual comprehension. Model of the study is a quasi-experimental design with a pretest-posttest control group. Since the classes are formed by the school management, one of these classes was assigned to the experiment group and the other one was assigned to the control group randomly. Before the practice pretests (Science Process Skills Test (SPST)) and Mathematics Attitude Scale (MAS) and after the practice the same test was implemented to the students in experiment and control group as posttests. Argumentation Willingness Scale (AWS) was implemented to only experiment group students as pretest and posttest. Two weeks after the practice conceptual comprehension test with open-ended questions was conducted with 6 students selected from experiment and control group students.

\subsection{Study Group}

This study was carried out with totally sixty 9th grade students studying in a city located in the Eastern Anatolian Region during the 2014-2015 educational years. In this study, two different classes from 9th grade were selected and one of them was assigned as the experiment group (20 female- 10 male) and the other one was assigned as the control group (17 female-13 male) randomly. While the functions subject was taught to the experimental group through argumentation method, it was taught to the control group through existing (traditional) teaching method.

\subsection{Practice}

Functions were taught to the experiment and control group students during the practice by the researcher. Functions were taught to the experiment and control group students through 6 class hours per week for 6 weeks. The control group was taught through the traditional teaching method in which the teacher is in lecturer position considering the maths curriculum and provides information directly, and the students are in listener position during the lesson and sometimes answer the questions of the teacher, the subject is followed by the course book and the questions at the unit 
ends are answered. However, the experiment group was divided into seven groups totally as 6 groups of four each and 1 group of six each and they dealt with the activities prepared by argumentation method throughout the function subject and did 9 activities totally during the practice. The students tried to prove the accuracy of their claims by the discussion with their group mates. Other students who did not believe in the accuracy of the claim tried to confuse the claims of their friends by throwing out a new claim. At the end of the activities the students shared the claim they defended with other group mates in the class. During this process, students interacted with their teachers constantly.

A discussion in the activity that used argumentation model in experimental group and the arguments appeared is as follows.

Activity:

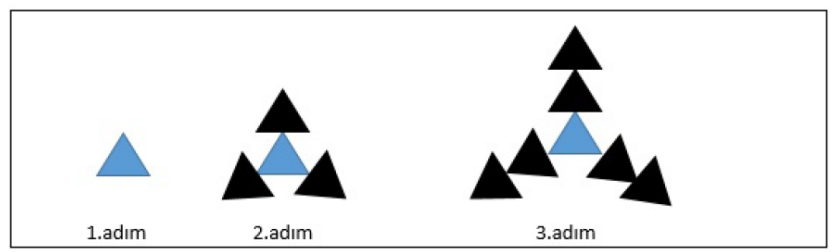

If you want to write the change rule of the above form as a function, what should this function be?

Discussion:

Sudent1: I think this is a linear function that implements the rule (Claim).

Sudent3: Yes, it is linear function (Support) It takes all of them equally and in the same way (Reason).

... (the function they found was as follows: $f(x)=3 x-2) \ldots$

Sudent3: I think only $3 n+1$ is true (Claim)

Sudent1: Look. For $n=1$, it gives $3 * 1+1=4$ (Confuting)

Sudent2: There is one triangle in the first step, so it cannot happen (Confuting)

As seen in the discussion, students created claim, support, reason and contradiction arguments.

\subsection{Data Collection and Analysis}

The data in this study were collected by open-ended conceptual understanding questions, mathematics attitude scale, science process skills tests and argumentation willingness scale. Conceptual understanding questions with 11 open-ended questions prepared by the researcher. Students were asked to explain the concept of function, its types, definition and domain. Conceptual understanding questions were analyzed by 2 experts in maths teaching and a research assistant in maths teaching and content validity of the test were provided by getting their opinions. Two weeks after the practice, this test was conducted in written with six each student selected from both experiment and control group students according to function success test post test results as high (2), medium (2) and low (2) points. After the test, the students who were thought to have misconceptions were interviewed for about five minutes.
Maths attitude scale (MAS) prepared by Kabaca [37] was used in order to measure the students' attitudes towards Maths. Some of the items in the test were as follow: "learning mathematics is a waste of time", "it is worthy to gain mathematical knowledge", "it is irritating to study mathematics". The scale was prepared in 5 points Likert-type including the statements of "totally I agree", "I agree", "I partly agree", "I don't agree". The reliability coefficient of MAS (Cronbach alpha) prepared by Kabaca [37] was found as .934. In the study reliability coefficient of the scale implemented to 9th-grade experiment and control group students was calculated as $\alpha=.951$. This scale was implemented to experiment and control group students as pretest and posttest.

The original of science process skill test was developed by Burn, Okey, and Wise [38] and it was translated into Turkish and adapted by Geban, Aşkar, and Özkan [39]. This test consists of 36 multiple choice questions with four choices. Reliability coefficient of SPST (Cronbach alpha) was calculated as .82 by Urban, Aşkar, and Özkan [39]. Reliability coefficient of the scale implemented to 9th-grade experiment and control group students was calculated as $\alpha=.752$ in the study. This scale was implemented to experiment and control group students as pretest and posttest.

Argumentation willingness scale was developed by Infante and Ranger [40] in order to identify the students' willingness and avoidance for argumentation and it was translated into Turkish and adapted by Kaya [41]. This test includes items such as "I like to stay away from discussion", "arguing on a topic creates a problem for me", "it is a pleasure to defend my claim about a subject" and "I do not want to be together with people who do not think the same with me". The test consists of 5 points Likert type of 20 questions containing "always", "often", "sometimes", rarely", "never" degrees. The reliability coefficient of the original of this test was found as .91. However, the reliability coefficient of the translated form was found as .71 by Kaya [41]. The reliability coefficient of the scale implemented to 9th-grade experiment group was calculated as $\alpha=.885$. This scale was implemented to the experiment and control groups as pretest and posttest.

As pretest and posttest, MAS and SPST were implemented to both experiment and control group students, but AWS was implemented to experiment group students. In order to determine whether score sharing of these implemented tests are normal or not, histogram, Box-plot, Q-Q plot graphics and normal sharing test (Shapiro-Wilks Test) were observed. Since pretest and posttest score sharing of MAS implemented to experiment and control group students was not normal, Mann-Whitney U Test was utilized. Since pretest and posttest score sharing of SPST implemented to both experiment and control group students was normal, independent t-test was utilized. Since pretest and posttest score sharing of AWS implemented only to experiment group students was normal, independent t-test was utilized. 
All analyses were tested at .05 significance level.

Descriptive analysis method was used in the analysis of the data obtained by open-ended conceptual comprehension conducted in order to examine thoroughly the conceptual comprehension of experiment and control group students trained by argumentation method. The data obtained from open-ended conceptual comprehension questions were evaluated by basing the table divided into 5 categories by Şekerci [22]. Categories and the details about these categories are presented in Table 2.1.

\section{Findings}

In this study where the Functions in Maths is taught through the activities basing upon the argumentation method, the comments and statistical analysis results about the obtained findings are presented as the following.

\subsection{Findings of SPST Pretest and Posttest Scores of Experiment and Control Group Students}

Since SPST pretest and posttest scores of experiment and control group in the study are normal, independent t-test results conducted in order to identify whether there is a statistical significance difference between pretest and posttest scores of experiment and control group are presented in Table 3.1.

As can be seen in Table 3.1, there is no statistically significant difference between SPST pretest and posttest scores of experiment and control group $(\mathrm{t}(58)=1.608 ; \mathrm{p}>.05)$.
However, we can see that there is a statistically significant difference between SPST pretest and posttest scores of the groups $(\mathrm{t}(58)=2.079 ; \mathrm{p}=.042<.05)$. Therefore, the fact that SPST posttest score average of experiment group students $\left(\bar{X}_{\mathrm{D}}=23.47\right)$ who are taught through argumentation method is higher than the scoring average of control group students $\left(\bar{X}_{\mathrm{K}}=20.73\right)$ who are taught through existing method indicates that this difference is on behalf of the experiment group.

\subsection{Findings of MAS Pretest and Posttest Scores of Experiment and Control Group Students}

Since MAS pretest and posttest scores of experiment and control group in the study are not normal, Mann-Whitney U test results conducted in order to identify whether there is a statistical significance difference between pretest and posttest scores of experiment and control group are presented in Table 3.2 .

When the analysis results in Table 3.2 are evaluated, we can see that there is no statistically significant difference between MAS pretest scores of experiment and control group $(U=332.500 ; p>.05)$. However, when MAS posttest scores of experiment and control group students are considered, we can see that there is a significant difference between these scores $(U=310.000 ; p<.05)$. Therefore, we can understand that MAS rank averages (35.17) of experiment group students who are taught through argumentation method are higher than the rank averages (25.83) of control group students who are taught through existing method.

Table 2.1. Categories Used in Analysing the Open-ended Conceptual Comprehension Questions

\begin{tabular}{|l|l|}
\hline \multicolumn{1}{|c|}{ Categories } & \multicolumn{1}{c|}{ Explanations } \\
\hline Clear Comprehension & Answers covering all aspects of the accepted answer \\
\hline Partly Comprehension & $\begin{array}{l}\text { Answers covering one aspect of the accepted answer, but not covering all aspects. Answers covering some } \\
\text { misconceptions along with some aspects of the accepted answer. }\end{array}$ \\
\hline Misconception & Academically wrong answers \\
\hline Non-comprehension & Repeating the question exactly, irrelevant or unclear answering \\
\hline Blank/No Answer & Not answering or answering as I don't know or I don't understand \\
\hline
\end{tabular}

Table 3.1. Independent t-Test Results According to SPST Pretest and Posttest Score Averages

\begin{tabular}{|c|c|c|c|c|c|c|c|}
\hline & Group & $\mathbf{N}$ & $\bar{X}$ & $\mathbf{S}$ & sd & $\mathbf{t}$ & $\mathbf{p}$ \\
\hline \multirow{2}{*}{ Pretest } & Experiment & 30 & 19.80 & 4.972 & \multirow{2}{*}{58} & \multirow{2}{*}{1.608} & \multirow{2}{*}{.113} \\
\hline & Control & 30 & 17.87 & 4.321 & & & \\
\hline \multirow{2}{*}{ Posttest } & Experiment & 30 & 23.47 & 4.240 & \multirow{2}{*}{58} & \multirow{2}{*}{2.079} & \multirow{2}{*}{.042} \\
\hline & Control & 30 & 20.73 & 5.819 & & & \\
\hline
\end{tabular}

Table 3.2. Mann-Whitney U Test Results for MAS Pretest and Posttest Scores

\begin{tabular}{|c|c|c|c|c|c|c|}
\hline & Group & N & Rank Average & Rank Total & U & p \\
\hline \multirow{3}{*}{ Pretest } & Experiment & 30 & 34.42 & 1302.50 & \multirow{2}{*}{332.500} & .082 \\
\cline { 2 - 5 } & Control & 30 & 26.58 & 797.50 & & \multirow{2}{*}{.038} \\
\hline \multirow{2}{*}{ Posttest } & Experiment & 30 & 35.17 & 1055.00 & 710.000 & .00 \\
\cline { 2 - 7 } & Control & 30 & 25.83 & 775.00 & & \\
\hline
\end{tabular}




\subsection{Findings of Conceptual Understanding of Experiment and Control Group Student}

Open-ended conceptual comprehension questions were conducted in order to examine thoroughly the conceptual comprehension of experiment group students trained through argumentation method and control group students trained through existing teaching method. Accordingly, the test consisting of open-ended conceptual comprehension questions were conducted in written form with six each student from both two groups. After the test, the students who were thought to have misconceptions were interviewed for about five minutes. The findings obtained from the analysis of the answers of the students to open-ended conceptual comprehension questions are presented in Table 3.3.

When the results in Table 3.3 are analyzed, we can see that the frequency of experiment group students including in clear understanding category in the answers of experiment and control group students to the conceptual understanding questions is higher than the frequency of control group students. Also, when the answers of the experiment and control group students including in misconception category, we can see that the answers of the experiment group students are lower than the answer of control group students. In other words, we can say that the lessons with argumentation method affect the conceptual understanding of the experiment group students positively.

\subsection{Findings of AWS Pretest and Posttest Scores of Experiment Group Students}

Since the sharing of AWS experiment group pretest and posttest is normal, the results of dependent t-test conducted to identify that there is a statistically significant difference between pretest and posttest scores of the experiment group are presented in Table 3.4. To the analysis results in Table 3.4 , we can see that there is a significant difference between AWS pretest $(\bar{X}=73.90)$ and AWS posttest $(\bar{X}=79.53)$ score averages of experiment group $(\mathrm{t}(29)=-3.741 ; \mathrm{p}<.05)$. Since the score averages of the posttest are higher than the score averages of the pretest, we can understand that this difference is on behalf of the posttest.

Table 3.3. Distribution of Student Answers to Open-Ended Conceptual Comprehension Questions According to Categories

\begin{tabular}{|c|c|c|c|c|c|c|c|c|c|c|}
\hline \multirow{2}{*}{$\begin{array}{c}\text { Categories } \\
\text { Items }\end{array}$} & \multicolumn{2}{|c|}{ Clear Comprehension } & \multicolumn{2}{|c|}{$\begin{array}{c}\text { Partly } \\
\text { Comprehension }\end{array}$} & \multicolumn{2}{|c|}{ Misconception } & \multicolumn{2}{|c|}{ Non-Comprehension } & \multicolumn{2}{|c|}{ No Answer } \\
\hline & $\begin{array}{l}\text { EG } \\
\text { (f) }\end{array}$ & $\begin{array}{l}\text { CG } \\
\text { (f) }\end{array}$ & $\begin{array}{l}\text { EG } \\
\text { (f) }\end{array}$ & $\begin{array}{l}\text { CG } \\
\text { (f) }\end{array}$ & $\begin{array}{l}\text { EG } \\
\text { (f) }\end{array}$ & CG(f) & $\begin{array}{c}\text { EG } \\
\text { (f) }\end{array}$ & $\begin{array}{l}\text { CG } \\
\text { (f) }\end{array}$ & $\begin{array}{l}\text { EG } \\
\text { (f) }\end{array}$ & $\begin{array}{l}\text { CG } \\
\text { (f) }\end{array}$ \\
\hline 1 & 3 & 1 & 3 & 2 & - & 1 & - & 2 & - & - \\
\hline 2 & 5 & 5 & - & - & 1 & 1 & - & - & - & - \\
\hline 3 & 5 & 3 & 1 & 1 & - & 2 & - & - & - & - \\
\hline 4 & 5 & 1 & 1 & 3 & - & 1 & - & 1 & - & - \\
\hline 5 & - & - & 5 & 3 & 1 & 2 & - & - & - & 1 \\
\hline 6 & 2 & 1 & 2 & 2 & 2 & - & - & 3 & - & - \\
\hline $7 a$ & 2 & 2 & 2 & 2 & 2 & - & - & 2 & - & - \\
\hline $7 b$ & 3 & 1 & 1 & 3 & 1 & 1 & 1 & - & - & 1 \\
\hline $7 \mathrm{c}$ & 3 & 1 & - & - & 1 & 4 & 2 & - & - & 1 \\
\hline 8 & 6 & 3 & - & - & - & 3 & - & - & - & - \\
\hline 9 & 5 & 4 & - & - & - & 2 & 1 & - & - & - \\
\hline 10 & 4 & 3 & 1 & - & - & 1 & - & - & 1 & 2 \\
\hline 11 & 5 & 4 & - & - & - & 1 & - & - & 1 & 1 \\
\hline
\end{tabular}

Table 3.4. Dependent t-Test Results of AWS Pretest and Posttest

\begin{tabular}{|c|c|c|c|c|c|c|c|}
\hline Group & & $\mathbf{N}$ & $\overline{\boldsymbol{X}}$ & $\mathbf{S}$ & $\mathbf{s d}$ & $\mathbf{t}$ & $\mathbf{p}$ \\
\hline \multirow{2}{*}{ Experiment } & Pretest & 30 & 73.90 & 13.732 & \multirow{2}{*}{29} & -3.741 & .001 \\
\cline { 2 - 8 } & Posttest & 30 & 79.53 & 11.852 & & \multirow{2}{*}{} \\
\hline
\end{tabular}




\section{Discussion and Conclusions}

Whether there is a significant difference between the SPST posttest averages of experiment group with argumentation method and the control group with the existing teaching method has been researched in this study. As a result of the research, it was found that there was a significant difference on behalf of the experiment group between SPST posttest score averages. According to this result, it can be said that argumentation method contributes to the science process skills of the students. The reason why the experiment group students who were implemented the argumentation method are more successful than the control group students is that students have the opportunity to argue in accordance with their own ideas and find out their knowledge in accordance with the conclusions they found in argumentation method while reaching information. However, in the existing teaching method students are directed to the conclusion with the theoretical information that is given to them and they do not have the opportunity to find out their own knowledge. In the studies conducted with the argumentation method in literature we do not see many studies analyzing the effect of students on science process skills. The result of Demircioğlu's [42] study that the science process skills of the students improved is paralleled with the result of this study. Also, Şekerci [22] in his study reached similar results and he stated that argumentation method was more effective than the existing teaching approach in terms of science process skills. In Myers and Dyer's [43] study that they conducted in order to analyze the effect of the used laboratory methods on science process skills of teacher candidates, the students with the questioning laboratory education got higher scores than the students with traditional laboratory education. In Aydoğdu and Ergin's [44] study open-ended and research based experiment techniques improved the science process skills of the students significantly compared to the traditional laboratory method.

It is foreseen that a student with positive attitudes towards Maths will be more successful $[45,46]$. Students' beliefs and attitudes affect their willingness for learning [47]. In order to improve students' Maths attitudes, many studies were conducted in teaching and were supported with different methods and techniques. In this study, Maths attitudes of experiment group students who were taught through argumentation were compared with the attitudes of control group students who were taught through the existing teaching method. We can see that there is a significant difference between the experiment and control group students' attitudes towards Maths and this difference is on behalf of the experiment group. The reason for the change in attitudes of the experiment group students trained with argumentation method towards Maths throughout the study as a result of their observations can be expressed as the fact that attendance and self-confidence of the passive students increased as the result of argumentation practices, these students began to search the reasons and results and they began to exhibit correct attitude about supporting their own ideas. In the studies concerning argumentation, it was reported that this affected the students' attitudes positively [22, 26, 48-51].

In addition, the effect of argumentation on the conceptual comprehension of 9th-grade students was compared with the existing teaching approach in this study. According to the obtained results, it can be said that argumentation method improved the conceptual comprehension of 9th-grade students about "Functions" unit. This improvement is on behalf of the experiment group that the argumentation method was implemented. This result also complies with the literature data [22, 26, 29, 41, 52-54]. Yalçın Çelik [26] in his study stated that 9 th and 10th-grade students who were practiced with academic argumentation method improved their conceptual comprehension about "pattern of the matter" and "gasses" unit.

According to argumentation willingness scale results implemented to the experiment group students before and after the practice, it can be seen that there is a statistically significant difference between the willingness of experiment group students for the argumentation within the period of the practice from the beginning to the end. As a result, it can be said that argumentation method is effective in improving the willingness of students for argumentation. It can be said that the fact that students begin to get the knowledge in a social pattern in a small group discussion, attendance willingness of irrelevant students to lessons increases in time and especially they exhibit the change for argumentation in the last three weeks increased the improvement of students' argumentation willingness. This result is paralleled with the result that argumentation method in the studies in literature increases the argumentation willingness [22, 26, 29, 41, 53]. Tekeli [29] in his study identified that the lesson with argumentation method increased the argumentation willingness of experiment group students at the end of practice as a result of statistical analyses.

This study is limited to 9th-grade students and "Functions" subject. Similar studies can be conducted by implementing in different classes on the other subjects in Maths curriculum. In order to generalize the argumentation activity, it can be applied in groups with more sampling. In this study, the efficiency of argumentation was compared with the existing teaching method. Studies in which argumentation is compared with different methods/ approaches can be conducted.

\section{REFERENCES}

[1] Beyazıt, İ. ve Aksoy, Y. (2013). Fonksiyon kavramı: Epistemolojisi, alg1 türleri ve zihinsel gelişimi. Erciyes Üniversitesi Fen Bilimleri Enstitüsü Dergisi, 29(1), 1-9.

[2] Eisenberg, T. (1991). Advanced Mathematical Thinking. In D. O. Tall (Ed.), Function and Associated Learning Difficulties, (pp.140-152), Kluwer Academic Publishers, Dordrecht 
[3] Clement, L., Edwards, B. and Graham K. (2001). What Do Students Really Know About Functions? Mathematics Teacher, 94(9), 745-749.

[4] Leinhardt, G., Zaslavsky, O., \& Stein, M. K. (1990). Functions, graphs, and graphing: Tasks, learning, and teaching. Review of Educational Research, 60(1), 1 -64.

[5] Markovits, Z., Eylon, B., and Bruckheimer, M. (1986). Functions today and yesterday. For the Learning of Mathematics, 6(2), 18-24.

[6] Vinner, S. (1983). Concept definition, concept image and the notion of function. International Journal of Mathematical Education in Science and Technology, 14(3), 293-305.

[7] Tall, D. and Vinner, S. (1981). Concept 1mage and concept definition in mathematics with particular reference to limits and continuity. Educational Studies in Mathematics, 12, 151-169.

[8] Güveli, E. ve Güveli, H. (2002). Lise 1 fonksiyonlar konusunda web tabanlı örnek bir öğretim materyali. V. Ulusal Fen Bilimleri ve Matematik Eğitimi Kongresi Bildiriler Kitabı, 866-872.

[9] Açıkgöz, K. Ü. (2002). Aktif öğrenme (6. Bask1). Eğitim Dünyası Yayınları, İzmir.

[10] Aldağ, H. (2005). Düşünme Aracı Olarak Metinsel Ve Metinsel-Grafiksel Tartışma Yazılımının Tartışma Becerilerinin Geliștirilmesine Etkisi. Çukurova Üniversitesi, SBE. Adana: Yayımlanmamış Doktora Tezi.

[11] Aldağ, H. (2006). Toulmin Tartışma Modeli. Çukurova Üniversitesi Sosyal Bilimler Enstitüsü Dergisi, 15(1), 13-34.

[12] Toulmin, S. E. (1958). The uses of argument. Cambridge, UK: Cambridge University Press.

[13] Erduran, S., Simon, S. and Osborne, J. (2004). Tapping into argumentation: developments in the application of Tolumin's argument pattern for studying science discourse. Science Education, 88(6), 915-933.

[14] Yackel, E. and Cobb, P. (1996). Sociomathematical norms, argumentation, and autonomy in mathematics. Journal for Research in Mathematics Education, 27(4), 458-477.

[15] Brown, R. and Reeves, B. (2009). Students' Recollections of Participating in Collective Argumentation When Doing Mathematics. In R. Hunter, B. Bicknell, and T. Burgess, Crossing divides Proceedings of the 32 nd annual conference of the Mathematics Education Research Group of Australasia (pp. 73-80). Palmerston North: MERGA.

[16] Brown, R. and Redmond, T. (2007). Proceedings of the 30th annual conference of the Mathematics Education Research Group of Australasia. Mathematics: Essential Research, Essential Practice, 1, 163-171.

[17] Mueller, M. F. (2009). The co-construction of arguments by middle-school students. Journal of Mathematical Behavior, 28, 138-149.

[18] Sanchez, M. G. C., and Uriza, R. C. (2008). Studying arguments in the mathematics classroom: a case study. Paper presented at the 11th International Congress on Mathematical Education, Monterrey, Mexico.

[19] Krummheuer, G. (2007). Argumentation and participation in the primary mathematics classroom two episodes and related theoretical abductions. Journal of Mathematical Behavior, 26, $60-82$.
[20] Küçük Demir, B. (2014). Argümantasyon tabanlı bilim öğrenme yaklaşımının öğrencilerin matematik başarılarına ve yaratıcı düşünme becerilerine etkisi. Yayımlanmamış Doktora Tezi. Atatürk Üniversitesi Eğitim Bilimleri Enstitüsü, Erzurum.

[21] Dinçer, S. (2011). Matematik Lisans Derslerindeki Tartışmaların Toulmin Modeline Göre Analizi. Yayımlanmamış Doktora Tezi. Hacettepe Üniversitesi Eğitim Bilimleri Enstitüsü, Ankara.

[22] Şekerci, A. R. (2013). Kimya Laboratuvarında argümantasyon odaklı öğretim yaklaşımının öğrencilerin argümantasyon becerilerine ve kavramsal anlayışlarına etkisi. Yayımlanmamış Doktora Tezi. Atatürk Üniversitesi Eğitim Bilimleri Enstitüsü, Erzurum.

[23] Okumuş, S. (2012). "Maddenin halleri ve 1s1" ünitesinin bilimsel tartışma (Argümantasyon) modeli ile öğretiminin öğrenci başarısına ve anlama düzeylerine etkisi. Yayımlanmamış Yüksek Lisans Tezi. Karadeniz Teknik Üniversitesi Eğitim Bilimleri Enstitüsü, Trabzon.

[24] Kaya, E. (2012, Haziran). Argümantasyona dayalı etkinliklerin öğretmen adaylarının kimyasal denge konusunu anlamalarına etkisi, X. Ulusal Fen Bilimleri ve Matematik Eğitimi Kongresinde sunulan sözlü bildiri, Niğde.

[25] Uluay, G. (2007). İlköğretim 7. sinıf fen ve teknoloji dersi kuvvet ve hareket konusunun ögretiminde bilimsel tartıșma (argümantasyon) odaklı öğretim yönteminin öğrenci başarısına etkisinin incelenmesi. Yayımlanmamış Yüksek Lisans Tezi. Kastamonu Üniversitesi Eğitim Bilimleri Enstitüsü, Kastamonu.

[26] Yalçın Çelik, A. (2010). Bilimsel tartışma (argümantasyon) esaslı öğretim yaklaşımının lise öğrencilerinin kavramsal anlamaları, kimya dersine karşı tutumları, tartışma isteklilikleri ve kalitesi üzerine etkisinin incelenmesi. Yayımlanmamış Doktora Tezi. Gazi Üniversitesi Eğitim Bilimleri Enstitüsü, Ankara.

[27] Ceylan, Ç. (2010). Fen Laboratuvar Etkinliklerinde Argümantasyon Tabanlı Bilim Öğrenme - ATBÖ Yaklaşımının Kullanımı. Yayımlanmamış Yüksek Lisans Tezi. Gazi Üniversitesi Eğitim Bilimleri Enstitüsü, Ankara.

[28] Özkara, D. (2011). Basınç konusunun sekizinci sınıf ögrencilerine bilimsel argümantasyona dayalı etkinlikler ile ögretilmesi. Yayımlanmamış Yüksek Lisans Tezi. Adıyaman Üniversitesi Fen Bilimleri Enstitüsü, Adıyaman.

[29] Tekeli, A. (2009). Argümantasyon odaklı sınıf ortamının öğrencilerin asit-baz Konusundaki kavramsal değişimlerine ve bilimin doğasını kavramalarına etkisi. Yayımlanmamış Yüksek Lisans Tezi. Gazi Üniversitesi Eğitim Bilimleri Enstitüsü, Ankara.

[30] Demirci, N. (2008). Toulmin'in bilimsel tartışma modeli odaklı eğitimin kimya öğretmen adaylarının temel kimya konularını anlamaları ve tartışma seviyeleri üzerine etkisi. Yayımlanmamış Doktora Tezi. Gazi Üniversitesi Eğitim Bilimleri Enstitüsü, Ankara.

[31] Dawson, V. M., and Venville, G. J. (2010). Teaching strategies for developing students' argumentation skills about socio-scientific issues in high school genetics. Research in Science Education, 40(2), 133-148. 
[32] Katchevich D., Hofstein, A. and Mamlok-Naaman, R. (2011, November 09). Argumentation in the chemistry laboratory: Inquiry and confirmatory experiments, Research in Science Education, Advance Online Publication. doi:10.1007/s11165-011-9267-9.

[33] Kind, P., Wilson, J., Hofstein, A. and Kind, V. (2010, March). Stimulating peer argumentation in the school science laboratory: exploring the effect of laboratory task formats. Paper presented at the meeting of the National Association for Research in Science Teaching, Philadelphia, USA.

[34] Karataş, İ. ve Güven, B. (2004). Fonksiyon Kavramının Farklı Öğrenim Düzeyinde Olan Öğrencilerdeki Gelișimi, Eurasian Journal of Educational Research, 4(16), 64-73.

[35] Çelik, D. (2007). Öğretmen adaylarının cebirsel düşünme becerilerinin analitik incelenmesi. Yayımlanmamış Doktora Tezi. Karadeniz Teknik Üniversitesi Fen Bilimleri Enstitüsü, Trabzon.

[36] Akkoç, H. (2005). Fonksiyon Kavramının Anlaşılması: Tanımsal Özellikler ve ÇoğulTemsiller. Eğitim Araştırmaları, 20, 14-24.

[37] Kabaca, T. (2006). Limit Kavramının Öğretiminde Bilgisayar Cebiri Sistemlerinin Etkisi. Yayımlanmamış Doktora Tezi. Gazi Üniversitesi Eğitim Bilimleri Enstitüsü, Ankara.

[38] Burn, C. J., Okey, J. R., \& Wise, K. C. (1985). Development of an integrated process skill test: TIPS II. Journal of Research in Science Teaching, 22(2), 169-177.

[39] Geban, Ö., Askar, P. and Özkan, D. (1992). Effects of computer simulations and problem-solving approaches on high school students. Journal of Educational Research, 86(1), 6-10.

[40] Infante, D. And Ranger, A. (1982). A conceptualization and measurement of argumenentativeness. Journal of Personality Assessment, 46, 72-80.

[41] Kaya, O. N. (2005). Tartışma teorisine dayalı öğretim yaklaşımının ögrencilerin maddenin tanecikli yapısı konusundaki başarılarına ve bilimin doğası hakkındaki kavramalarına etkisi. Yayımlanmamış Doktora Tezi. Gazi Üniversitesi Eğitim Bilimleri Enstitüsü, Ankara.

[42] Demircioğlu, T. (2011). Fen ve teknoloji öğretmen adaylarının laboratuvar eğitiminde argüman temelli sorgulamanin etkisinin incelenmesi. Yayımlanmamıs Yüksek Lisans Tezi. Çukurova Üniversitesi Sosyal Bilimler Enstitüsü, Adana.

i This manuscript has been a part of $\mathrm{PhD}$ dissertation by Emel Mercan, supervised by Assoc. Prof. Dr. Tevfik İşleyen
[43] Myers, B. E., \& Dyer, J.E. (2005). Effects of investigative laboratory instruction on content knowledge and science process skill achievement across learning styles. American Association for Agricultural Education, San Antonio, TEXAS, $32,132-145$

[44] Aydoğdu, B., \& Ergin, Ö. (2008). Fen ve teknoloji dersinde kullanılan farklı deney tekniklerinin ögrencilerin bilimsel süreç becerilerine etkileri. Ege Eğitim Dergisi 9(2), 15-36

[45] Reyes, L. H. (1984). Affective Variables and Mathematics Education. The Elementary School Journal, 84, 558-580.

[46] Ma, X. (1997). Reciprocal Relationships Between Attitude Toward Mathematics and Achievement in Mathematics. The Journal of Educational Research, 90(4), 221-229.

[47] Özden, Y. (2003). Öğrenme ve Öğretme. Pegem Yayıncılık, Ankara.

[48] Akkus R., Gunel M., \& Hand B. (2007). Comparing an inquiry-based approach known as the science writing heuristic to traditional science teaching practices: Are there differences? International Journal of Science Education, 29 (14), $1745-1765$

[49] Günel, M., Kabatas Memis, E. ve Büyükkasap, E. (2010). Yaparak yazarak bilim öğrenimi-YYBÖ yaklaşımının ilköğretim öğrencilerinin fen akademik başarısına ve fen dersine yönelik tutumuna etkisi. Eğitim ve Bilim, 35 (155), 49-62.

[50] Kaya, N. O., Doğan, A. ve Kılıç, Z. (2005). University students" attitudes towards chemistry laboratory: Effects of argumentative discourse accompanied by concept mapping. Gazi Eğitim Fakültesi Dergisi, 25(2), 201-213.

[51] Keys, C.W., Hand, B., Prain, V. and Collins, S. (1999). Using the science writing heuristic as a tool for learning from laboratory investigations in secondary science. Journal of Research in Science Teaching, 36, 1065-1081.

[52] Clark, D. B. and Sampson, V. (2007). Personally-seeded Discussions to Scaffold online argumentation. International Journal of Science Education, 29(3) 253-277.

[53] Uluçınar Sağır, Ş. (2008). Fen bilgisi dersinde bilimsel tartışma odaklı öğretimin etkinliğinin incelenmesi. Yayımlanmamış Doktora Tezi. Gazi Üniversitesi Eğitim Bilimleri Enstitüsü, Ankara.

[54] Zohar, A. and Nemet, F. (2002). Fostering students' knowledge and argumentation skills through dilemmas in human genetics. International Journal of Research in Science Teaching, 39(1), 35-62. 